University of Rhode Island

DigitalCommons@URI

2012

\title{
Climate Change Impacts on International Seaports: Knowledge, Perceptions, and Planning Efforts Among Port Administrators
}

\author{
Austin Becker \\ University of Rhode Island, abecker@uri.edu \\ Satoshi Inoue \\ Martin Fischer \\ Ben Schwegler
}

Follow this and additional works at: https://digitalcommons.uri.edu/maf_facpubs

Terms of Use

All rights reserved under copyright.

\section{Citation/Publisher Attribution}

Becker, A., S. Inoue, M. Fischer and B. Schwegler. (2012). "Climate change impacts on international seaports: knowledge, perceptions, and planning efforts among port administrators." Climatic Change 110(1-2): 5-29.

Available at: http://www.dx.doi.org/10.1007/s10584-011-0043-7

This Article is brought to you for free and open access by the Marine Affairs at DigitalCommons@URI. It has been accepted for inclusion in Marine Affairs Faculty Publications by an authorized administrator of DigitalCommons@URI. For more information, please contact digitalcommons-group@uri.edu. 


\title{
CLIMATE CHANGE IMPACTS ON INTERNATIONAL SEAPORTS: KNOWLEDGE, PERCEPTIONS, AND PLANNING EFFORTS AMONG PORT ADMINISTRATORS
}

\author{
Austin Becker ${ }^{1}$, Satoshi Inoue ${ }^{2}$, Martin Fischer ${ }^{3}$, Ben Schwegler ${ }^{4}$ \\ 1. PhD Candidate, Emmett Interdisciplinary Program in Environment and Resources \\ 2. Visiting Professor, National Graduate Institute for Policy Studies, Tokyo, Japan \\ 3. Director, Center for Integrated Facility Engineering; Professor, Civil and \\ Environmental Engineering, Stanford University \\ 4. Chief Scientist of Walt Disney Imagineering $R \& D$ and Consulting Professor at \\ Stanford University
}

\begin{abstract}
Seaports are located in vulnerable areas to climate change impacts: on coasts susceptible to sea-level rise and storms or at mouths of rivers susceptible to flooding. They serve a vital function within the local, regional, and global economy. Their locations in the heart of sensitive estuarine environments make it an imperative to minimize the impacts of natural hazards. Climate impacts, like a projected SLR of .6m to $2 \mathrm{~m}$ and doubling of Category 4 and 5 hurricanes by 2100, will result in more extreme events at many seaports. To assess the current state of knowledge on this issue, we surveyed port authorities from around the world about how administrators felt climate change might impact their operations, what sea-level change would create operational problems, and how they planned to adapt to new environmental conditions. The planned rapid expansion of ports reported by the survey respondents indicates that adaptation measures should be considered as ports construct new infrastructure that may still be in use at the end of the century. Respondents agreed that the ports community needs to address this issue and most felt relatively uninformed about potential climate impacts. Although most ports felt that SLR would not be an issue at their port this century, sea-level rise was nevertheless an issue of great concern. Our results suggest opportunities for the scientific community to engage with port practitioners to prepare proactively for climate change impacts on this sector.
\end{abstract}

KEY WORDS

Seaports, Climate Change Adaptation, Climate Change Impacts, Climate Change Planning

Cite as:

Becker, A., S. Inoue, M. Fischer and B. Schwegler (2012). "Climate change impacts on international seaports: knowledge, perceptions, and planning efforts among port administrators." Climatic Change 110(1-2): 5-29.

Corresponding Author:

Austin Becker

austinb@stanford.edu

401-636-0430 


\section{Introduction}

The nature of their business locates seaports in one of the most vulnerable areas to climate change impacts: in coastal areas susceptible to sea-level rise (SLR) and increased storm intensity or at mouths of rivers susceptible to flooding. $90 \%$ of the world's freight moves by ship (IMO 2008). Thus, seaports play a crucial role in the global economy as transportation hubs for the vast majority of goods transported around the world. Given shipping's efficiencies and its smaller carbon footprint relative to other modes of transport, ${ }^{1}$ as well as forecasted increases in world freight volumes, demands on ports are likely to grow in the coming century (Transportation Institute 2008). To remain efficient and resilient, seaports must anticipate the impacts of climate change and proactively prepare for SLR, increased flooding, and more frequent extreme storm events (Hallegate 2008; PIANC 2008; UNCTAD 2008; EPA 2008). National and international organizations have identified that climate impacts on maritime infrastructure is an area of great concern in which little work has been completed (PIANC 2008; UNCTAD 2008; USCOP 2004; EPA 2008).

To assess the current state of knowledge, we sent surveys to 342 port authorities from around the world to ascertain how administrators feel climate change might impact their operations, what sea level change would create operational problems, and how they plan to adapt to new environmental conditions. Specifically, we aimed to discover what policies, if any, ports already have in place to address adaptation issues. $63 \%$ of the 93 respondents reported that they had at least one policy that specifically addressed potential climate change effects or that they discussed adaptation in staff meetings. We also asked questions to check whether certain categories of ports were more or less proactive. The survey responses showed few significant differences between ports of different sizes or regions, but indicated that US Gulf Coast ports appeared to be the most prepared. This higher level of preparedness is probably due to the large number of recent storms in the Gulf.

The design lifetime of port infrastructure is 30-50 years, but often infrastructure like roads, bridges, piers, and rail yards will last much longer (UNCTAD 1985). Much infrastructure built today will still stand as climatic conditions change over the course of the century. As these projects compete for resources with other business or community needs, long-range implications of today's choices often have less of a sense of urgency than more immediate priorities. Our survey results indicate that capital planning cycles at ports are typically 5 to 10 years. This mismatch between planning cycles and infrastructure lifetimes may be at the root of many structural organizational difficulties in addressing this complex issue.

We hope that this survey will stimulate discussion in the academic, policy, and practitioner communities about climate adaptation. Should there be a global policy to prescribe longer planning horizons than currently practiced? Or, a unified design standard

${ }^{1}$ Carbon calculations estimate: Air cargo - 1.7739 lbs. CO2 per ton-Mile; truck - 0.3725 lbs. CO2 per ton-Mile; train - 0.2306 lbs. CO2 per ton-mile; sea freight -0.0887 lbs. CO2 per ton-mile. See

www.carbonfund.org/site/pages/carbon_calculators/category/Assumptions 
storm resistance? Do we need a better database of historical storm events and their impacts in order to better understand risks and vulnerabilities? Should policies be global? By GDP? By risk of exposure to storms? How can the scientific community tailor research and communication about climate change and its likely impact to the various functions of a port? These questions and others require data that the results of our survey begin to provide.

Results show that the world port community is very concerned with impacts of climate change, but generally feels the need for more specific information from the scientific community to make good decisions. This situation must be resolved if decisions are to be made that will protect both the port infrastructure itself and the economic systems that depend on a resilient and efficient maritime industry.

\section{Climate change impacts on ports}

The evidence that the climate system is warming is unequivocal. Projections of climate change suggest new problems for the world and for coastal communities in particular (IPCC 2007; Karl 2009; EPA 2008). Coastal communities face direct threats to urban areas and indirect ramifications due to impacts of extreme events on the global economy and linked environmental ecosystems. The nature of these threats depends on how much and how quickly climate changes, what steps are taken to limit climate change, and what actions are taken to reduce vulnerabilities and increase resilience. The uncertainties in future projections, together with the potentially serious impact on the oceans, lakes, and river systems of the world, create new demands for assessing and adaptively managing risks. As noted in a recent National Academy of Sciences report, "The parameters of the new climate regime cannot be envisioned from past experience ... Decision makers will need new kinds of information and new ways of thinking and learning to function effectively in a changing climate" (NRC 2009).

Climate change will require adaptation strategies for waterborne commerce and coastal infrastructure, the backbone of the global market economy. Additionally, seaports are generally located in estuarine areas where fresh-water rivers meet salt-water harbors. These fragile and critical nurseries for marine life demand a high level of protection from the effects of contamination and toxic-material release. To keep this sector efficient and resilient and coastal waters free from the devastating effects of catastrophe-induced pollution, seaport decision-makers must anticipate the impacts of climate change and proactively prepare for SLR, increased flooding, and more frequent extreme storm events (Hallegate 2008; PIANC 2008; Pielke 2007; EPA 2008). Research shows that proactive adaptation to reduce vulnerabilities is far more cost-effective than mitigation or reactive strategies (Pielke 2007; Stern and Britain 2006).

Current forecasts range from one-half to two meters of SLR by 2100 and project an overall shift toward meteorological instability including changes in storm frequency and intensity (IPCC 2007; Nicholls 2007; Rahmstorf 2007). One recent study projects a doubling of category four and five hurricanes in the Atlantic basin by 2100 (Bender et al. 2010). Other climate change impacts include temperature extremes that could affect how cargo is handled (i.e., more refrigeration or air-conditioning units may be needed). More extreme precipitation events could cause localized flooding and changes to sedimentation loading that could increase dredging requirements. SLR, storms, and flooding create interruptions and bottlenecks in the flow of products through ports and, as witnessed in 
Hurricane Katrina, can devastate a regional economy and environment for months or even years after an event and have national impacts (Esteban et al. 2009; Hallegatte 2008). That storm caused $\$ 1.7 \mathrm{~B}$ of damage to southern Louisiana ports and over 200 onshore releases of hazardous chemicals or petroleum products (Santella et al. 2010). Port shutdowns in Mississippi impacted commerce in 30 states (PEER 2006). The Port of Gulfport, for example, experienced total devastation. Containers from the terminals washed up throughout the downtown area. Piers and warehouses were destroyed. Customers relocated and five years later the port operates at $80 \%$ of its pre-Katrina volume. Gulfport now plans to build new facilities at 25' above base-flood elevation. In another event, Hurricane Ike caused $\$ 2.4 \mathrm{~B}$ of damage to Texas ports and waterways (FEMA 2008). In recent decades, an average of 130 ports were hit or brushed by a tropical cyclone each year (Figure 1).

Figure 1 - Map of tropical cyclone tracks 1990-2008

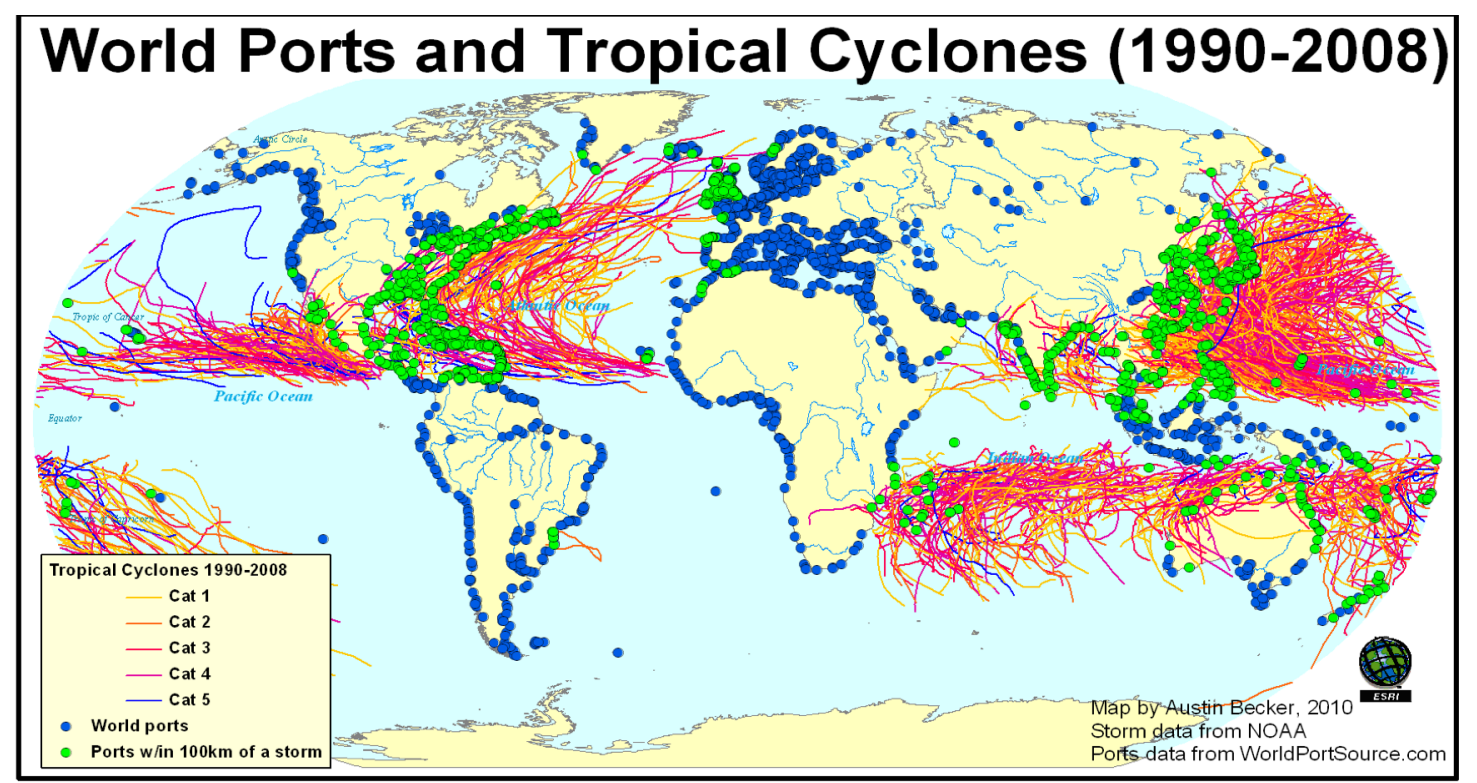

In a 2007 study, Nicholls et al. analyzed 136 port cities around the world to quantify current and future exposure to a 1-in-100 year flooding event. Their findings suggest that many of these areas have significant percentages of their GDP in areas that are at high risk today and climate change will increase that risk significantly. By 2070, for example, the combined effect of climate change, urbanization, increased population, and land subsidence could put 150-million people and US $\$ 35,000$ billion ( $9 \%$ of projected global GDP) of assets at direct risk (Nicholls 2007). Though their study focused on "port cities," as opposed to the ports themselves, the results serve as a useful indicator to the urgency of climate-change adaptation for the ports that are economic engines for these regions. Even outside of catastrophic damages, ports can expect "downtime" to increase with climate change. Larger storms in Japan, for example, could lead to more port shutdowns. Esteban (2009) shows that without taking proactive steps toward adaptation, the increased frequency of wind events could reduce the potential Japanese GDP by between 1.5 and $3.4 \%$ by 2085 . Hallegate (2007) looked more specifically at the 
impact of hurricane intensity and found that just a $10 \%$ increase in storm intensity would increase annual hurricane damages in the US by $54 \%$, from $\$ 8$ billion to $\$ 12$ billion per year. Another recent study found that surrounding port lands at 35 of 44 Caribbean ports will be inundated by $1 \mathrm{~m}$ of SLR, unless protected by new coastal structures (Simpson et al. 2010).

Climate change will disproportionately affect ports and port-based economies, depending on their geographic location and the adaptive capacities of the ports themselves and the communities in which they are located. For example, ports in lowlying areas in a hurricane belt will face different physical challenges than those on emergent coastlines far removed from storm-impact belts. Ports in developing nations will have a different suite of options available to them than those in developed nations (Dasgupta et al. 2008; Nicholls 2007). Ports located in estuaries that provide nursery environments for marine life have an even greater responsibility to protect coastal waters. The complexity and potential risks require the scientific community, policy makers, and the port authorities themselves to take an active role to understand better when and how to implement proactive adaptation strategies.

Ports fulfill a wide variety of functions for the local, regional, and global economy. They provide jobs, they facilitate trade, and they serve as critical links between the hinterlands (region from which goods come from) and the forelands (the region to which goods are destined). Ports range in specialization from massive container ports (i.e., Los Angeles/Long Beach), to small niche ports that serve one type of freight (e.g., petroleum, coal, grain, or fishing) (Hoyle and Knowles 1992).

Ports can be categorized in numerous ways, but ultimately are difficult to compare. Size may be measured by throughput, cargo value, land footprint, or other measures. Similarly, operation and ownership vary widely from port to port, with some being fully privatized and others being entirely public entities. Ports generally fall into one of four categories in terms of operations and management. "Service ports" are predominantly public. Generally a "port authority" owns the land and all assets and manages all cargo handling operations. The "tool port" divides responsibility between the port authority, which owns and maintains the infrastructure, and private firms, which handle the cargo. In a "landlord port," the port authority owns the land and infrastructure, but leases it to private operating companies. Finally, the "private service port" is entirely owned and operated within the private sector (Brooks 2004).

Since 2006 the International Association of Ports and Harbors (IAPH) and the American Association of Port Authorities (AAPA) have placed climate change high on their agendas. The IAPH has been working mostly on projects to mitigate climate change, such as the development of the IAPH Tool Box for Port Clean Air Programs and ISO/IEC technical standards for on-shore power supply. The IAPH launched the World Ports Climate Initiative (WPCI) in 2008. Presently, seven WPCI projects are in progress, all of which aim to reduce $\mathrm{CO}_{2}$ emissions from port-related activities. ${ }^{2}$ In 2009, the IAPH

\footnotetext{
${ }^{2}$ Following the World Ports Climate Conference held in Rotterdam in July 2008, IAPH launched the World Ports Climate Initiative (WPCI) in November 2008 as a global platform to assist ports, IAPH members and non-members alike, to effectively address climate change. At present, seven projects are in progress; IAPH Tool Box Vesion2, Carbon Footprinting, Intermodal Transport, Lease Contract Template, Cargo Handling
} 
tasked a technical committee to study adaptation measures to help ports prepare for risks of climate change. A technical report on the subject is expected sometime in 2011.

The AAPA also has focused on the mitigation of climate change. One recent conference showcased numerous efforts by many ports to reduce emissions by electrifying trucks and cranes and installing on-shore power supply to ships, thus reducing emissions from shipboard power plants while in port (AAPA 2010). However, as found in a recent United States Environmental Protection Agency (EPA) report on climate impacts on seaports, "most [US] ports do not appear to be thinking about, let alone actively preparing to address, the effects of climate change" (EPA 2008). To meet these challenges, decision makers must understand the nature of the problem, how it will impact local conditions, and what options may be considered. Policy makers, insurers, the international community, and the ports themselves will all play a role.

\section{Related survey research}

We believe this is the first survey to address this sector of the global economy on climate change adaptation. We hope it can serve as a model for studying seaports and other economic sectors such as airports, energy infrastructure, and intermodal freight systems. At least two similar surveys have been conducted on a smaller scale. A group from Texas A\&M conducted a survey in 2005 and 2006 entitled, "Port Planning and Views on Climate Change." The survey focused on the central question, "Is planning for climate change on the radar screen of the USA seaport industry?" This survey targeted only USA ports and found that about half of the 27 respondents felt climate change would affect their ports. Of those, a slight majority was taking at least initial steps to plan for it (Bierling and Lorented 2008). The State of California conducted a survey of its major coastal facilities. Results indicate that marine facilities in California are generally not considering climate change or SLR, which is projected to reach 1.4 meters in the State by 2100 (CSLC 2009). Another survey focusing on coastal managers in California found similar results (Moser and Tribbia 2006). Other surveys have been conducted to ascertain perceptions amongst wider audiences with regard to climate change (Leiserowitz 2008). Our survey focused on how port administrators are treating climate adaptation at their port, as opposed to the level of belief they had in the issues or the accuracy of their knowledge about climate science.

\section{Methods}

\subsection{Survey purpose}

In developing next steps to address the needs of the ports community, it is important to ground truth assumptions and learn more about how to best focus further research efforts. As a first step toward this goal and to ascertain if/how port authorities plan to adapt to climate change impacts on operations, this exploratory survey ascertained

Equipment, Environment Ship Index and On Shore Power Supply. Thus, while the world port community is fully aware of urgent need to address climate change, as clearly shown by the line-up of WPCI projects they are focusing on mitigation but not adaptation yet. See http://www.wpci.nl/home/index.php. 
current perceptions and strategies around the impacts of climate change on future international port operations. We set out to address the following questions:

1) What are ports' planning horizons in terms of infrastructure development, timelines, and incorporating climate changes?

2) What assumptions are they basing long-range plans upon? How is climate change discussed at the port and amongst the port community?

3) What do port directors think the local and regional impacts will be?

What types and scale of changes in this century would be problematic to their operations?

The survey focused primarily on adaptation issues for ports. It was explained in the survey instrument itself that "mitigation" refers to ways a port might reduce its impact on climate change through reducing $\mathrm{CO}_{2}$ emissions, while "adaptation" refers to how a port might adapt to anticipate the impacts of climate change such as SLR and storm surges.

\subsection{Sample}

The survey targeted a wide variety of port authorities in an attempt to sample ports in developing and developed nations, and ports in geographic areas with varying amounts of risk to ocean storms. It is difficult to generate a precise count of ports in the world. Marinas, fishing harbors, jetties, river ports, and others could all be considered "ports." As of 2010, the database "WorldPortSource" contained 4,235 entries from 195 countries. We focus only on those ports that are engaged in facilitating the transport of cargo. WorldPortSource included 1,056 entries as "seaports" ranging in size from "small" to "deep-water." This database includes inland ports, like those on the Great Lakes, in the seaport category. Though we first attempted to generate contact emails from a sampling of these 1,056 ports, this task proved to be wrought with difficulties. Identifying the appropriate ports, locating email addresses for port directors, and concerns with language limitations led to a refinement of the sample to the membership of two leading port organizations. The IAPH and AAPA memberships together represent 342 ports from around the world which are likely the largest and most important ports in terms of global marine commerce. IAPH, for instance, represents only a small part of the world's ports, with its membership being 208 ports from 90 countries, yet its member ports combined handle more than $60 \%$ of the world maritime cargo and $90 \%$ of the world container traffic. The IAPH is recognized as the only international organization representing the voice of the world port industry. It was granted Consultative Status as Non-governmental Organization from five United Nations specialized agencies and one intergovernmental body (IAPH 2010). Most ports that play a critical role in international trade and are interested in global issues are likely to be members of one or both of these groups. Additionally, this sampling approach makes the results more useful to the individual organizations and their members and improved the response rate.

\subsection{The survey tool}

The online survey was designed with input from the two port associations. The 30 questions were easy to complete and appropriate for an international audience that speaks 
and reads English. Representatives from the Environmental and Engineering Committees of the AAPA, as well as from the IAPH, the World Port Climate Initiative (WPCI), and others reviewed and pretested the survey tool. This helped insure that the questions and response options were easily understood and the questions were appropriate for the audience. The survey should have taken about 10-15 minutes for most respondents.

Questions covered four categories. "Port Planning Horizons" asked questions about plans for expansion, length of planning frames, and how climate change adaptation and storm impacts are addressed in long-range plans. "Climate Change Information" explored how respondents treat the topic of climate change in their community. For example, one question asked how frequently climate change adaption is discussed in staff meetings, either formally or informally. "Local and Regional Climate Change" asked questions about respondents' perceptions of climate impacts in their regional context. These questions asked about specific impacts, like how often flooding is already a problem, as well as thoughts on how much SLR could be a problem in the future. Finally, a section on "Port Characteristics" ascertained some basic information about size, location, and types of cargo handled at each port. ${ }^{3}$

\subsection{Distribution and responses}

The survey was distributed by the AAPA and IAPH to member ports in August 2009 online through Survey Monkey, a web-based software product designed for conducting surveys through the Internet. Survey Monkey allowed for wide distribution at low cost. AAPA's membership included 160 ports and IAPH membership represented 208 ports. There was some overlap, as some ports were members of both organizations, though this was minimal. We received 108 responses to the survey, 93 of which were usable. We deemed responses with no questions answered and completed surveys that appeared to be exact duplicates of one another to be unusable. We retained and included in our analysis answers from partially-completed surveys. Non-response was an issue, though response was more than adequate for the purposes of an initial survey (Alreck and Settle 1995). Non-response may have a number of causes. Port directors are very busy. They may not see climate change as an area of concern. Language barriers may also have been an issue. Though most member ports use English, some may have been reluctant to fill out a survey written in English if it was not their first language. Response rate was likely improved by obtaining the endorsement of the AAPA and IAPH port organizations and having invitations to participate sent out ahead of time. Reminding participants that the results would be used to determine international research agendas also helped. The original response deadline was extended and numerous reminders were emailed to ports by both organizations.

\footnotetext{
${ }^{3}$ The full questionnaire and results can be found online as part of a working paper at: http://cife.stanford.edu/Publications/index.html.
} 


\subsection{Overview of responses and port characteristics}

Figure 1 - Map of survey respondents

\section{Climate Change Survey Respondents}

IAPH and AAPA

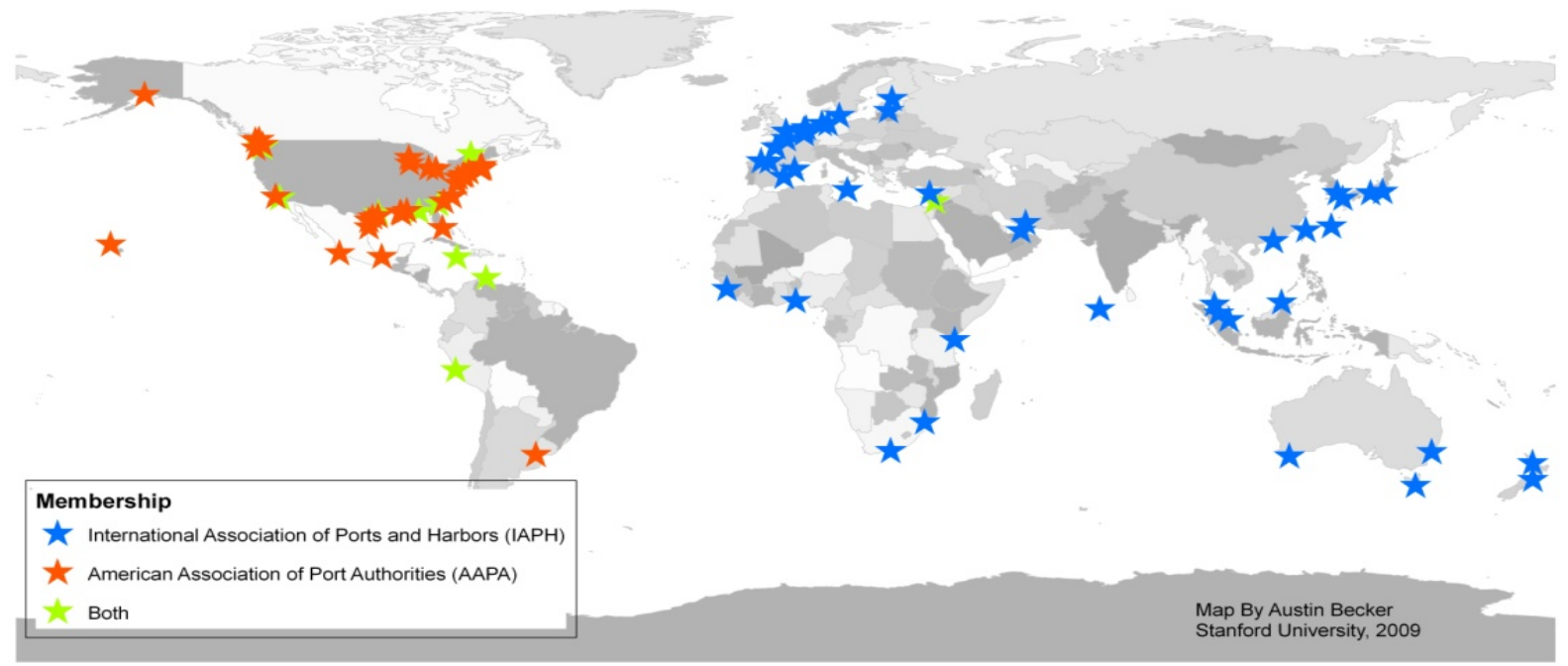

Ninety-three port directors, engineers, environmental managers, and planners representing 89 ports responded to the survey giving a broad picture of the current state of the world's ports with respect to climate change (Figure 1). In four cases, multiple respondents responded on behalf of a single port. These were retained as unique responses and the analysis was conducted using all 93 responses. The ports themselves were binned into a variety of categories for some parts of the analysis. Ports were assigned to a region based on the UN's definition of macro-regions (United Nations Statistics Division 2009). In the UN framework, North America and Latin America \& Caribbean are together in the macro-region "Americas," but since the majority of survey responses came from North America, the two sub-regions were treated distinctly in this analysis as "North America" and "Latin America/Caribbean." 
Table 1 - Table of respondent membership and region

\begin{tabular}{|c|c|c|c|c|c|c|}
\hline Region & $\begin{array}{l}\text { World } \\
\text { ports* }\end{array}$ & $\begin{array}{c}\text { IAPH/ } \\
\text { AAPA } \\
\text { Member }\end{array}$ & $\begin{array}{l}\% \text { Member of } \\
\text { IAPH/ } \\
\text { AAPA }\end{array}$ & $\begin{array}{c}\# \text { of } \\
\text { Respondents }\end{array}$ & $\begin{array}{l}\text { Respondents } \\
\text { as } \% \text { of } \\
\text { IAPH/AAPA } \\
\text { membership }\end{array}$ & $\begin{array}{l}\text { Respondents as } \% \text { of } \\
\text { world ports }\end{array}$ \\
\hline Oceania & 43 & 10 & $23 \%$ & 4 & $40 \%$ & $9 \%$ \\
\hline Africa & 82 & 19 & $23 \%$ & 5 & $26 \%$ & $6 \%$ \\
\hline $\begin{array}{l}\text { Latin } \\
\text { America/Ca } \\
\text { ribbean }\end{array}$ & 101 & 61 & $60 \%$ & 7 & $11 \%$ & $7 \%$ \\
\hline Europe & 274 & 51 & $19 \%$ & 17 & $33 \%$ & $6 \%$ \\
\hline Asia & 394 & 104 & $26 \%$ & 17 & $16 \%$ & $4 \%$ \\
\hline $\begin{array}{l}\text { North } \\
\text { America }\end{array}$ & 155 & 97 & $63 \%$ & 43 & $44 \%$ & $28 \%$ \\
\hline Total & 1049 & 342 & $33 \%$ & 93 & $27 \%$ & $9 \%$ \\
\hline
\end{tabular}

The IAPH and AAPA emailed the survey link to the port director of each member port, as the knowledge and perceptions of the port director serve as a reliable indicator of how seriously the port staff as a whole considers these issues. Though there may be others at the port with a deeper understanding or different perspective, ultimately the port director generally makes the final decision on long-term strategic plans (Mike Christensen, personal communication, February 2009). Although we hoped that the port director would answer the survey personally, responses were accepted from any staff member deemed appropriate by the director. Thus, actual responses were received from various departments within the port. The largest response categories were Port Director (26\%) and Environmental Team (23\%). Engineers, policy makers, safety department, and planners made up the remainder of the respondent roles. Respondents were fairly seasoned and $53 \%$ had over 16 years of experience in the maritime industries.

We divided ports into categories based on ownership and operations. There is no established and universally accepted framework for port classification, so two questions were designed that follow often-used conventions (Bichou and Gray 2005). The first question asked how ports were owned and operated, with $50 \%$ reporting as public, $42 \%$ as public/private, and $5 \%$ as private only. The second question classified ports as landlord, tool, service/operating, and private. $41 \%$ of respondents identified as "Landlord Ports," that is, they are port-authority owned, but terminals are operated by private leaseholders. 15\% identified as "Service/Operating Ports" in which terminals are owned and operated by a public port authority. $22 \%$ were "Tool Ports" in which infrastructure and superstructure is publicly owned, but cargo is handled through private operators. 5\% were fully privatized and the remainder did not answer this question.

Since proximity to ocean storms or coastal areas might influence preparation, attitudes and plans for climate change, we categorized ports as "within a storm belt" and "outside of a storm belt." These factors were teased out of the data through a GIS 
analysis and a question about port location with respect to sea routes. ${ }^{4} 44 \%$ were located in an area that has been within $150 \mathrm{~km}$ of a hurricane, cyclone, or typhoon in the past 150 years. Finally, ports were divided into categories based on their geomorphology. Some ports are on rivers or lakes and others are exposed to open ocean. Of those that answered a question about their location with respect to the coast, $84 \%$ reported to be within $50 \mathrm{~km}$ of the coast. So, most will therefore see some impacts from SLR and storm surge.

\section{Results}

Results describe how port authorities were considering adaptation strategies, what science they considered for their long-range plans, and the information they found necessary to plan for facility maintenance and growth, while addressing likely climate change impacts in the coming century. We will first provide an overview of the responses and characteristics of the ports surveyed. Next we will discuss port-planning horizons and climate change planning that is currently being implemented or considered at ports. Finally, we will discuss respondents' attitudes and perceptions about climate change adaptation. Generally, we found that most results showed little variation between regions. We note the regional differences, where we found them. ${ }^{5}$

\subsection{Port Planning Horizons and Climate Change Strategies}

Many respondents were considering, or at least discussing, climate change impacts. We assessed how ports discussed adaptation and mitigation measures within their organization by asking how often the topics came up in staff meetings (Figure 2). Respondents reported a higher frequency of mitigation meetings over adaptation meetings. Those who reported meetings that focused exclusively on mitigation also had meetings exclusively dedicated to adaptation. However, outside of the 8 respondents that fell on the extremes (frequent or never discussed), most reported that they did not discuss either topic with much frequency.

\footnotetext{
4 This analysis used NOAA's GIS dataset of 150 years of storm tracks. $150 \mathrm{~km}$ was chosen as an average 30 knot wind radius of a Cat 1 storm, as a minimum $150 \mathrm{~km}$ radius can be expected if wind speeds are sustained at $30 \mathrm{knots}$ or more and, 'Any wind which is higher than 30 knots $(55.56 \mathrm{~km} / \mathrm{h})$ will generally lead to a precautionary cessation of many human activities. Therefore any geographical point within the 30 knot radius of the storm will be considered to be suffering downtime due to that storm.' (see Esteban 2009). ${ }^{5}$ As noted above, these may be found at http://cife.stanford.edu/Publications/index.html.
} 


\section{Mitigation and Adaptation Discussions}

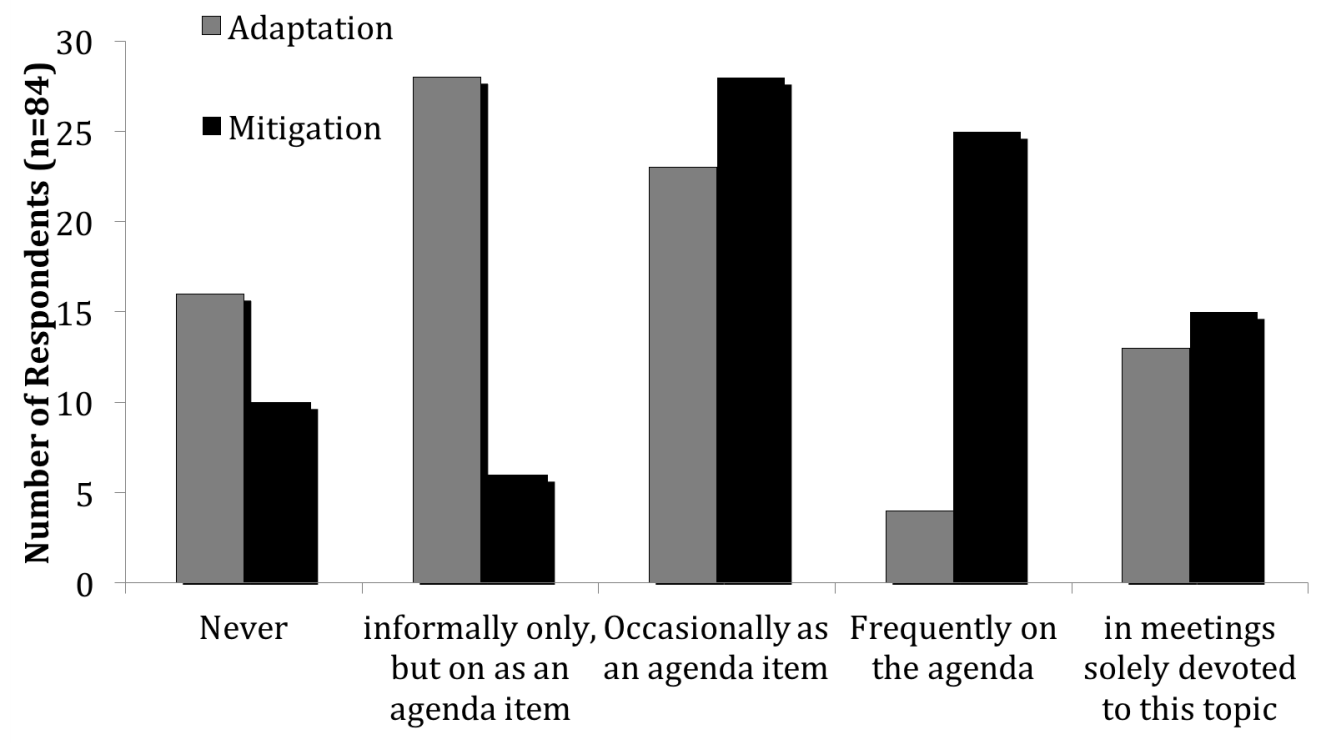

Frequency of Topic Discussion at Staff Meetings

When answers were analyzed by region, distance to storm belts, and proximity to the coast, no clear pattern emerged that indicates ports were discussing the issue of adaptation differently. However, privatized ports and tool ports appeared to be discussing these issues less frequently, as did Asian and European ports when compared to those from other regions.

To establish a general sense of how ports plan for future expansion and development of their infrastructure and cargo-handling facilities, we asked about planning horizons and specific plans for future projects. Though, of course there are various "planning horizons" for different types of projects and outcomes, the survey asked specifically about plans for capital improvements, expansion, and maintenance. We found that most ports plan on a 5-10 year horizon (Figure 3) and the majority are planning for some level of expansion of their facilities. 
Figure 3 - Ports' planning horizons in years

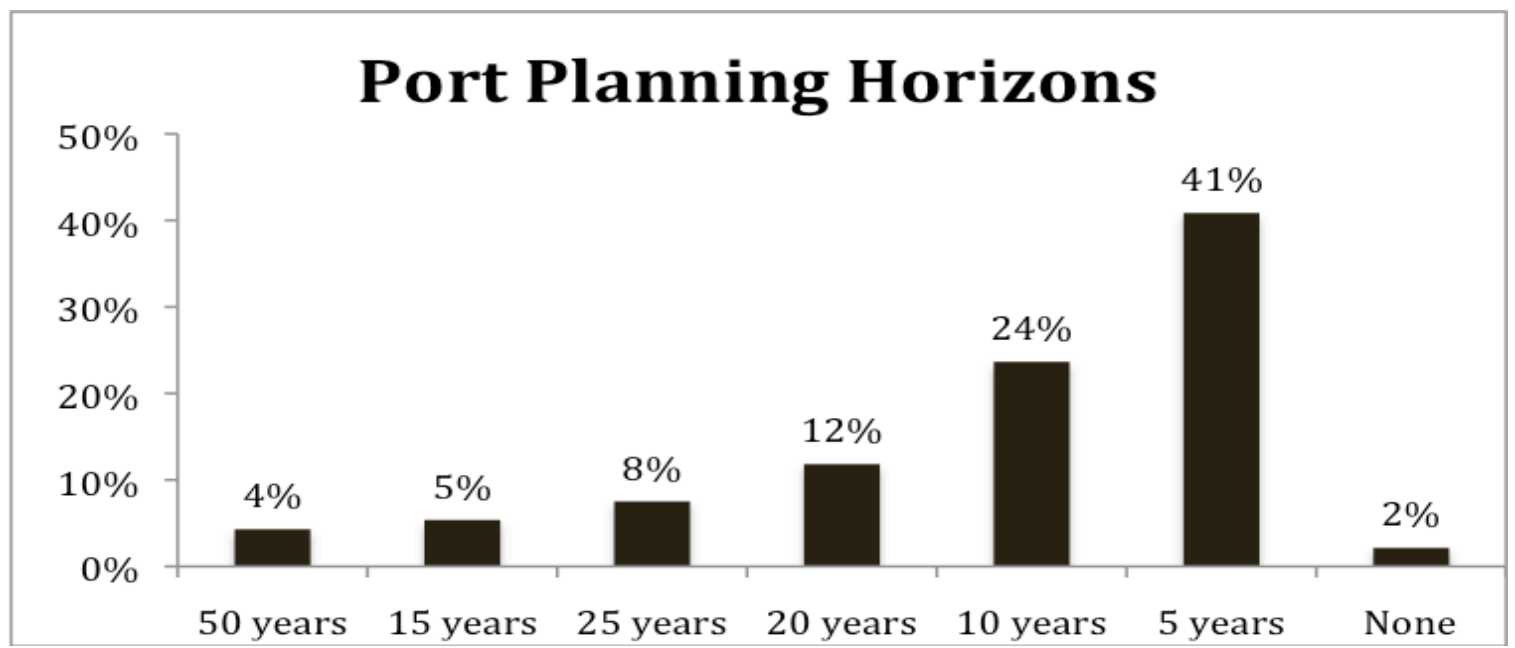

Those with planned projects indicated that most plans were for more terminals and berths or for land acquisition (Figure 4). Only a small percentage of ports have upcoming projects like new breakwaters or storm barriers that would increase their defenses against flooding and wave damage. The specific risks associated with climate change are no different in nature than historic risks. Most ports face some amount of wind, wave, and flooding risk already and have already built infrastructure to protect port operations. However, the degree of risk will likely change as storms become more intense and sea levels rise.

Only three ports $(3.2 \%)$ planned to build only protective structures. $22 \%$ had no plans to develop within the next 10 years.

Figure 4 - Expansion and improvement plans

\section{Expansion and Improvement Projects in Next 10 Years}

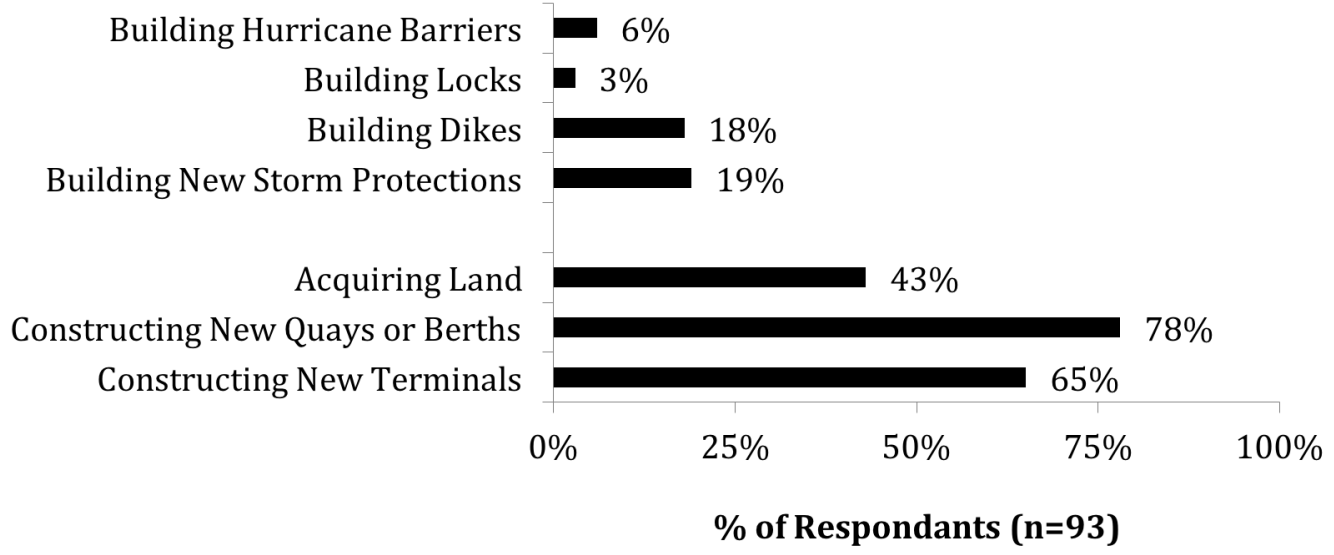




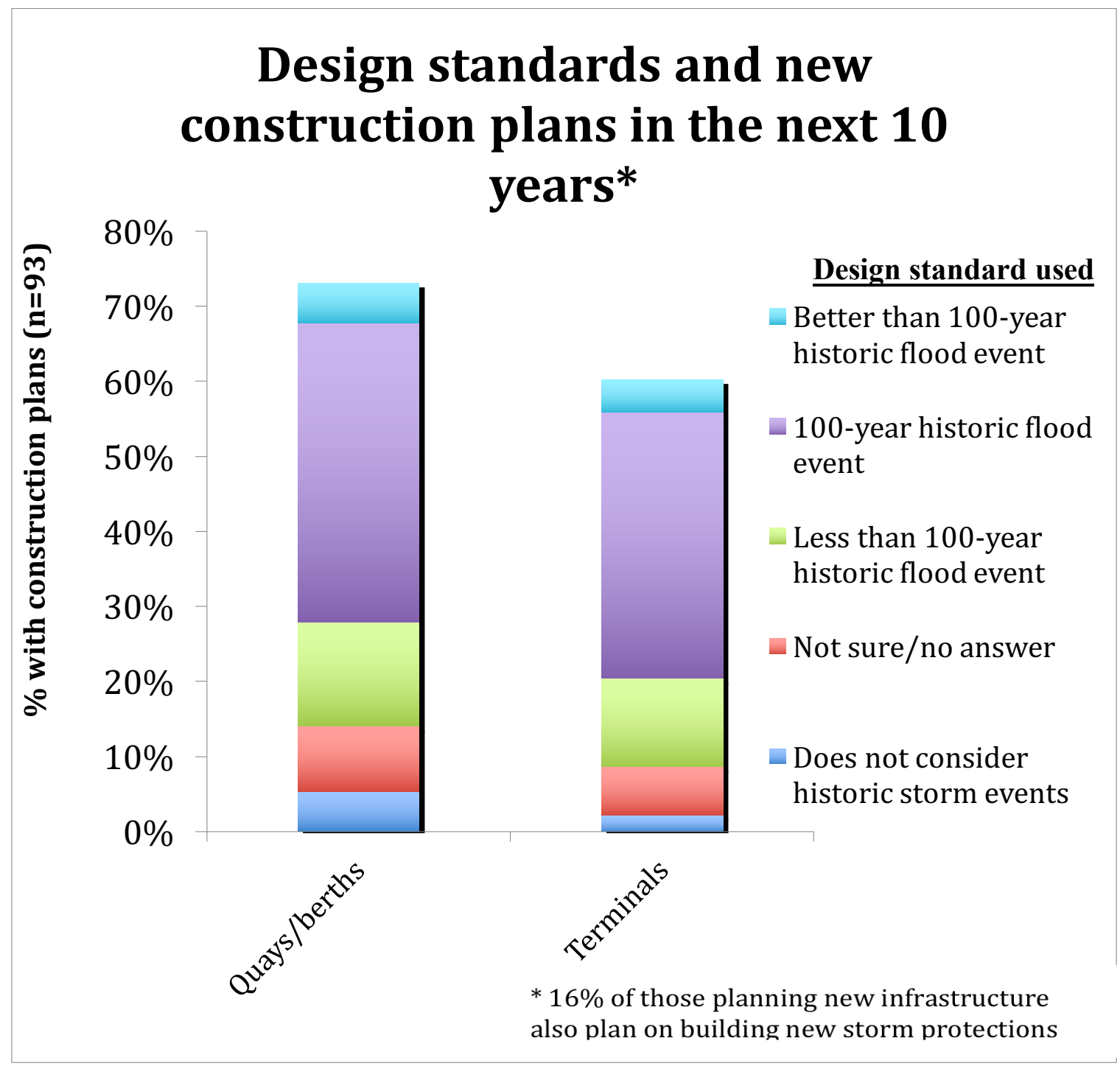

Since most respondents represent ports that are in coastal areas prone to storm events, they will likely design new structures with a particular extreme event threshold in mind. Survey results indicate that most ports in Europe, North America, and Oceania followed this 100-year return period planning standard. This means that a structure will be designed to withstand a storm that has a one-percent chance of occurring in any given year. However, $30 \%$ of Asian ports and $43 \%$ of ports in Central/South America planned with the most recent storm in mind. A few ports planned for a much longer return period, with one port answering that they planned for a 1-in-1000 year storm event. It should be noted that storm forces are different in different areas of the world. For example, a 1-in1000 year event in the Netherlands has roughly the same forces as a 1-in-100 year event in New Orleans. Thus, there is no universal storm period standard for designing structures to withstand storm events and it may not be feasible for all areas to implement such a high standard as the 1-in-1000 year event (Peter Wijsman, personal communication, May 15, 2009). 
The survey also asked how respondents thought about impacts on their port facilities and what measures they already had in place to address climate change concerns (Figure 6). The first closed-answer question asked which issues are currently considered at the port with respect to climate change. We generated the list to cover issues that we expected some ports to already have begun to address with input from the IAPH and AAPA. The majority (57\%) considered air pollution/air quality issues and $47 \%$ thought about potential impacts on the surrounding community and environment. These two concerns fall on the "mitigation" side of climate change issues and indicate that about half of the ports have already started to consider ways to address their contributions to climate change. The longer-term ramifications of climate change, such as market shifts or equipment needs, were generally not being considered at the time of the survey. These could be considered to fall more on the "adaptation" side of climate change.

Figure 6 - Climate change considerations

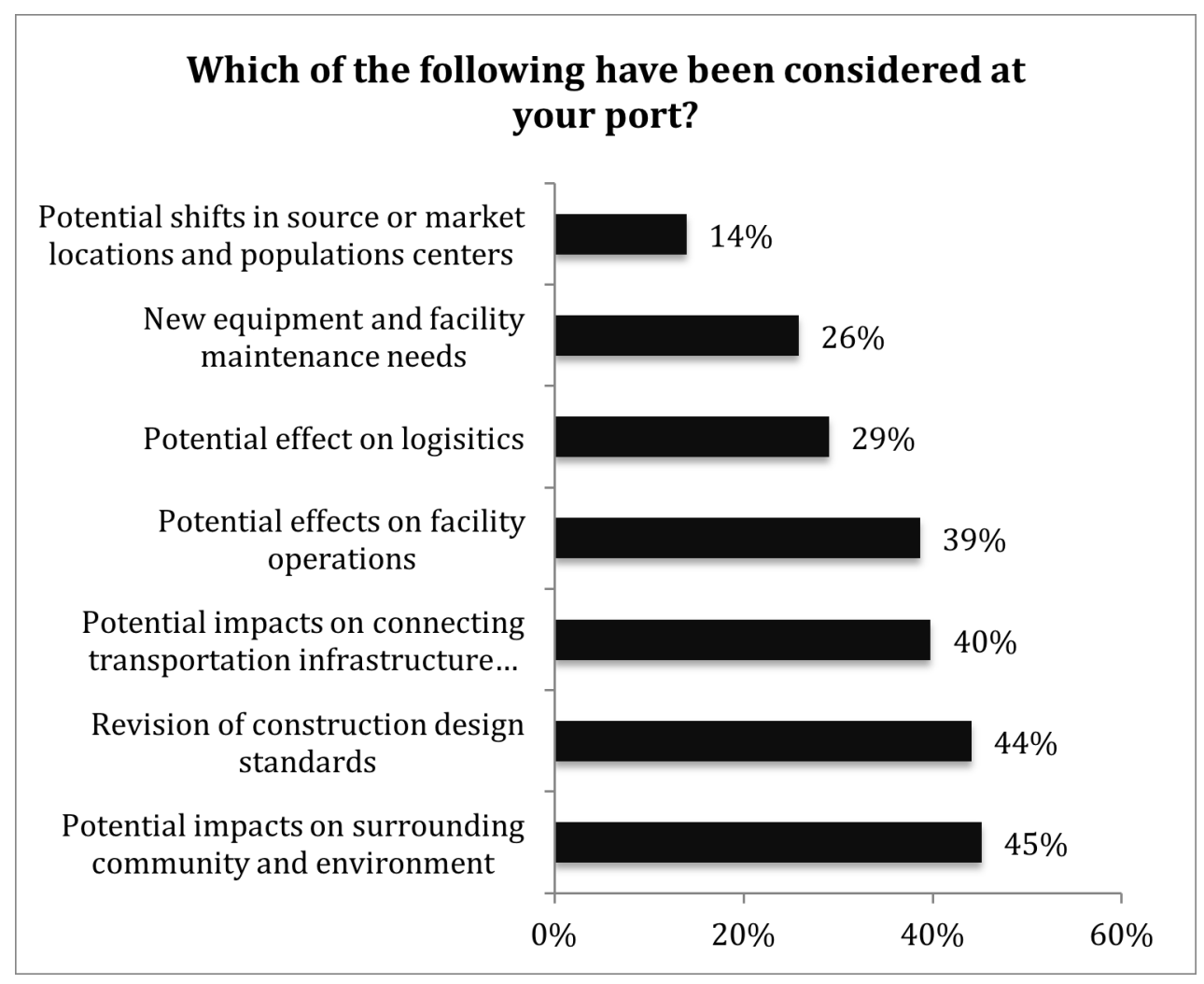

To get a better sense of what policies had already been actually implemented at the port, we developed a list of seven policies that we felt might reasonably have been adopted. We combined the answers from these two questions to sum up the "climate change related policies in place" shown in Figure 7 below. Many respondents either did not know or said they were not addressing these issues at this time (47\%). When asked about protective measures currently in place at the port, we found only $22 \%$ of respondents have a storm plan in place and only $23 \%$ carried specific storm insurance. We found no correlation between a port's location relative to the storm belt and its plans 
to develop new protective structures in the next 10 years, nor between insurance coverage and protection plans.

Figure 7 - Climate policies in place

\section{Climate adaptation policies in place}

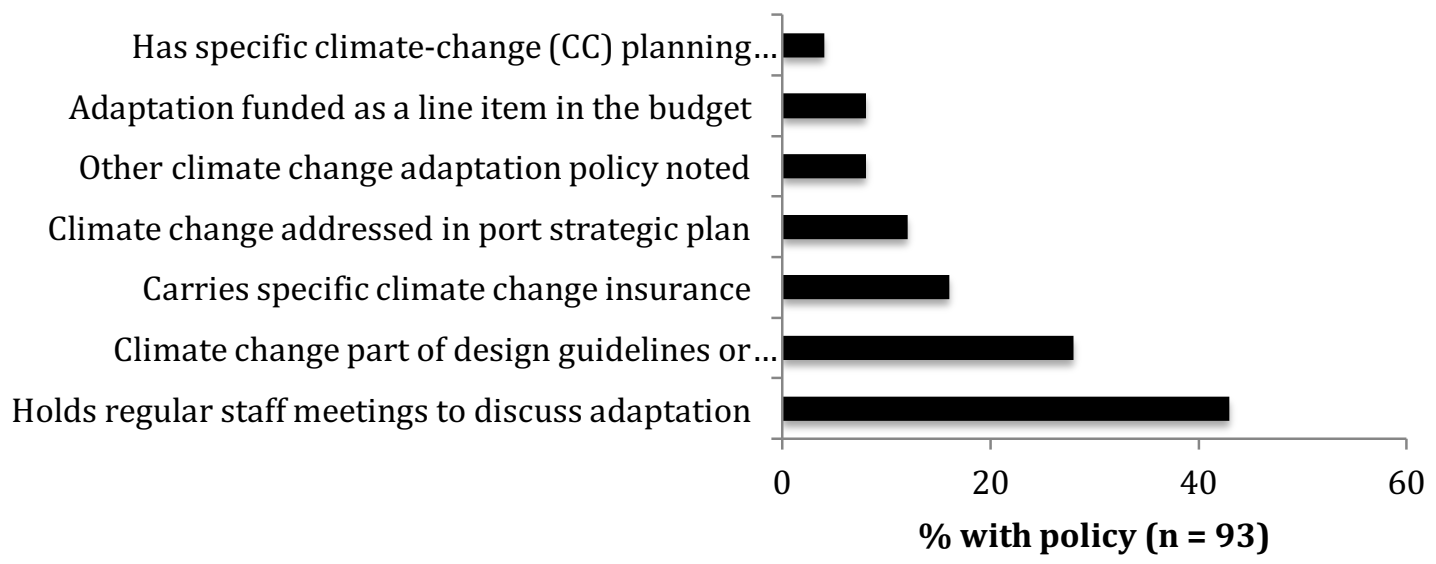

To make some comparisons, we developed a rough scoring system based on the answers to questions about policies in place and frequency of staff meetings devoted to climate change adaptation. We assigned a point for each answer selected from the list of choices and tallied the points for each port. The highest "score" was a five, meaning that the respondent indicated that the port had five of the potential seven options in place. The lowest score was a zero and the mean for all ports was 1.18 (1.24 standard deviation). Although this scoring system is not perfect, it enables us to make some rough comparisons between ports. We compared ports by size, World Bank status, location, and other categorizations. Figure 8 shows this analysis, with the number of ports in each category indicated in parenthesis and the average score indicated on the y-axis. Most comparisons showed little or no significant difference. However, ports that carried standard insurance averaged 1.5 points, a bit higher than those that were self-insured (1.17), carried co-op insurance (0.7), or carried no insurance at all (1.3). Geographically, ports located in high-income nations averaged 1.3, 1.0 in upper and middle-upper income averaged $1.0,0.75$ in low income $(0.75)$, and 0.5 in lower-middle income nations. 
Figure 8 - Adaptation plan scores by category

Number of responses for each category indicated by number in parenthesis. Score indicated on vertical axis.

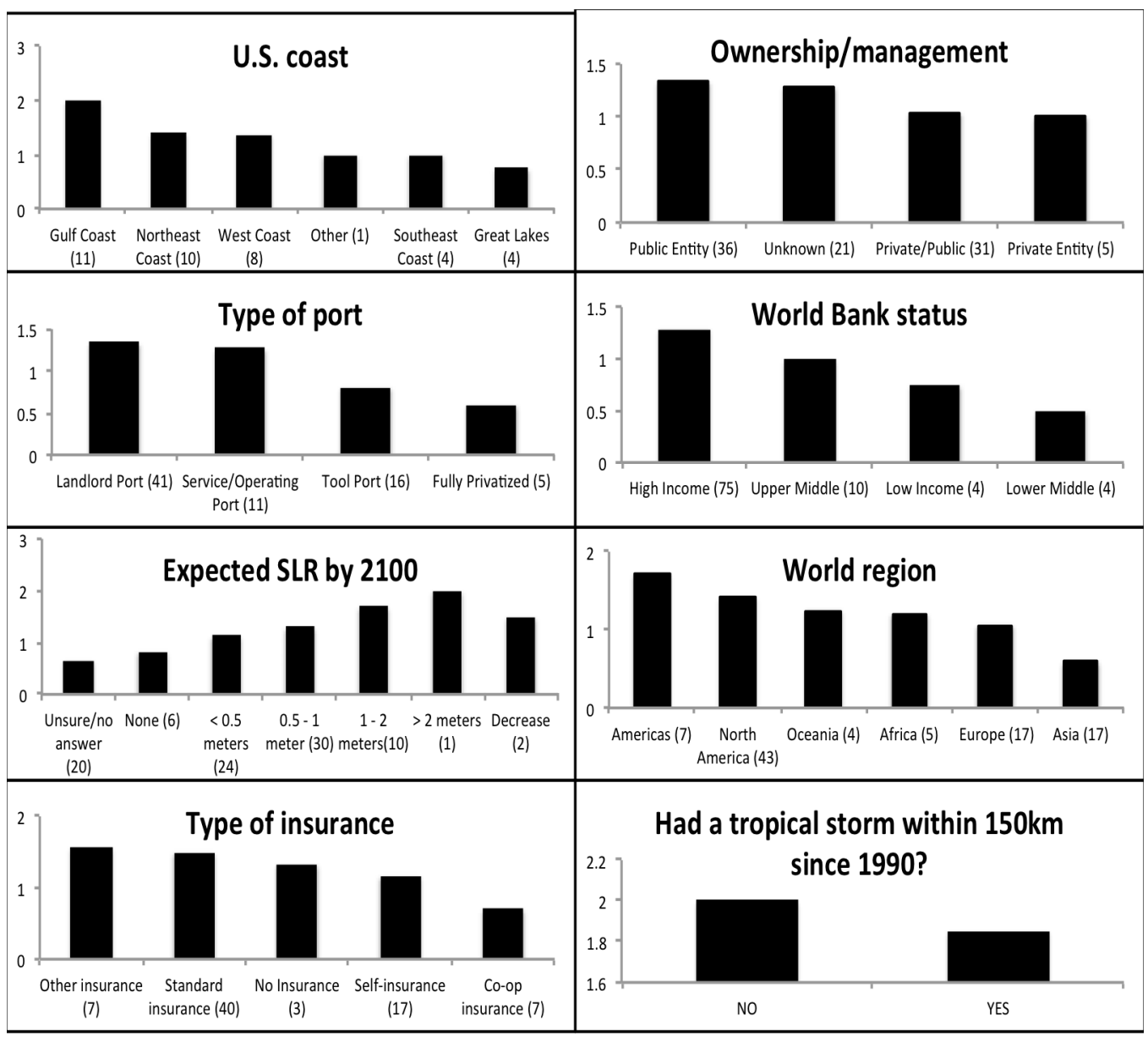

$\mathrm{N}=93$ Max score $=5$ Min score $=0$ Mean score $=1.18 \mathrm{Std}$. Dev $=1.24$

This scoring system offers insights into how ports compare relative to current climate preparation. In most cases, scores were within a standard deviation $(\mathrm{SD}=1.24)$ of each other. Our finding that high-income nations have more policies in place could be an initial step in discovering which ports have already thought about adaption problems and could provide models for those wishing to develop similar programs. Additionally, further investigation should be directed at the difference we found between ports with standard insurance versus ports with other types of insurance in place. Perhaps, for example, insurance companies are requiring ports to implement new policies. The highest scoring category was Gulf Coast Ports (with an average score of 2). Gulf Coast Ports have faced numerous hurricanes in the past decade. Land subsidence is also considerably greater on the Gulf Coast. These factors may contribute to the higher scores of these ports. 


\subsection{Climate change perceptions and attitude}

An open-ended question asked respondents to list the top three impacts climate change might have on their port's operations. This question was designed to elicit a wide range of responses, both positive and negative. The "word cloud" (Figure 9) represents the number of times a particular concern was listed by the size of the font. The more often a concern was listed, the larger the font.

Figure 9 - Top three concerns about climate change

Larger font indicates response was listed with higher frequency. www.wordle.net

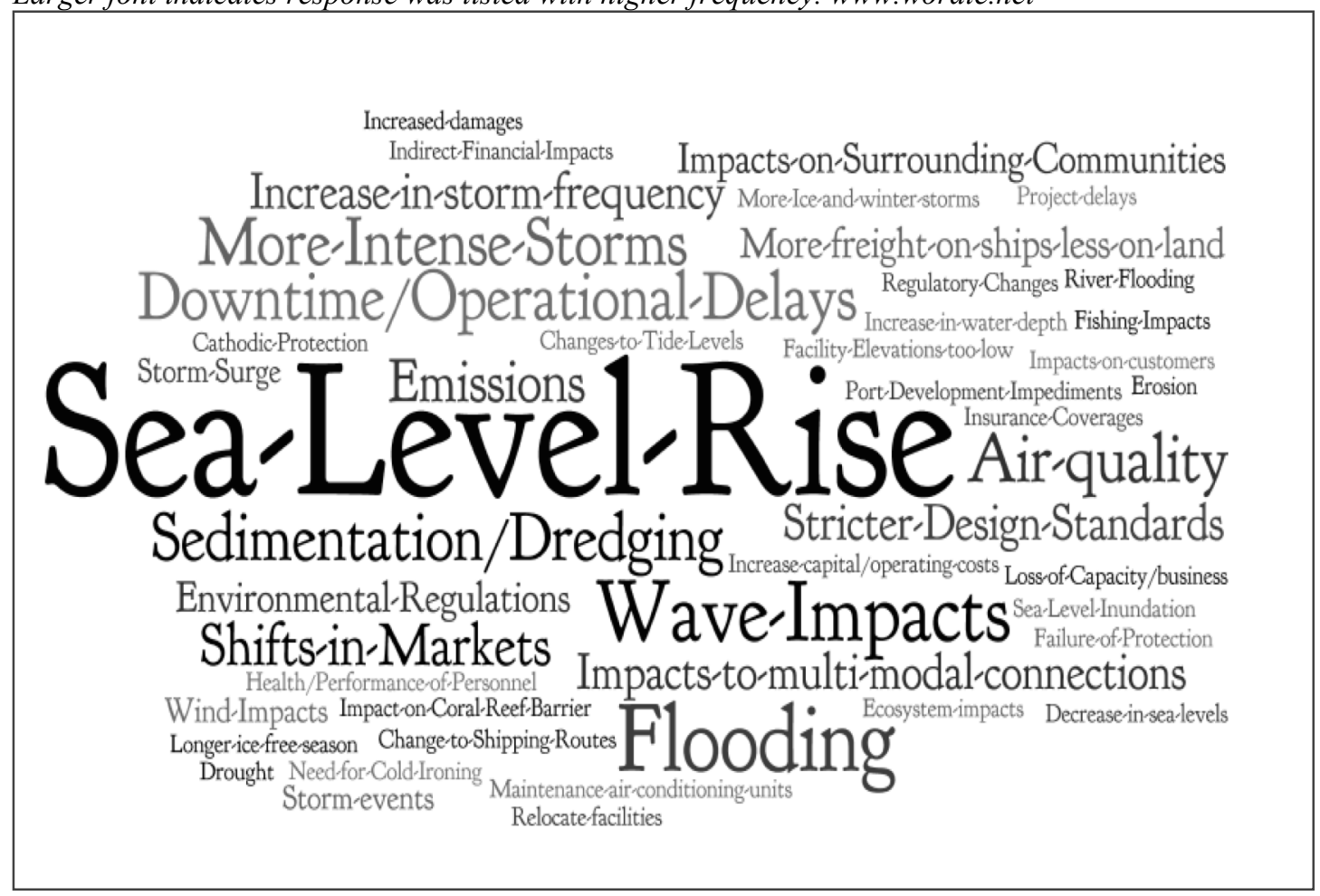

SLR was the chief concern among respondents. It was listed 27 times. Other impacts of note included storms, flooding, shifts in markets, wave and wind impacts, environmental regulations, and dredging. Given the average score of 1.18 climate policies in place, we were surprised at the level of concern for SLR and storm related issues.

When respondents were asked if they felt "informed" about climate change, the majority (66\%) answered negatively. "Informed" of course, is subjective, so this question was designed to assess the respondents' own perception of their knowledge around the issues. On a department or job function level, respondents who were planners tended to feel the most informed about climate change (60\% of planners), while other departments either did not feel informed at all (marketing, public relations and policy departments) or only about a third of respondents felt informed ( $\mathrm{CEO} /$ port directors, operations, safety/security, environmental departments).

While it is telling to see how respondents felt about their own knowledge, it is also revealing to see that most respondents considered climate change adaptation to be an important topic that they should know more about. $86 \%$ of respondents agreed that, "climate change should be addressed by the ports community as a whole". The few minor 
exceptions were from engineers (29\% disagreed), CEOs ( $24 \%$ disagreed), and environmental managers (17\% disagreed).

We also asked respondents their opinions about climate change and how it might impact their port. Interestingly, about half thought climate change would bring new opportunities. The open-ended responses represented in Figure 9 give some indication of the types of opportunities: changes to sea routes and shifts from land-borne to sea-borne freight movement. $42 \%$ of respondents foresaw direct negative consequences and $67 \%$ felt that the ports community has a role to play in reducing emissions.

As represented in Figure 10, respondents were very concerned about SLR. We asked two questions specifically about SLR. The first asked how much rise was expected by 2100 . The second asked how much SLR would be a problem if no new protections were built. $38 \%$ expected a SLR of $0.5-1 \mathrm{~m}$ by 2100 and $15 \%$ expected $1 \mathrm{~m}$ or more. When asked what would be a problem, $39 \%$ felt that $.5 \mathrm{~m}-1 \mathrm{~m}$ would be a problem, $58 \%$ felt that $1 \mathrm{~m}-2 \mathrm{~m}$ would be a problem, and $83 \%$ felt that over $2 \mathrm{~m}$ would be a problem Figure 10). While most respondents were concerned with a rise in sea level, those from the Great Lakes were very concerned with a drop in lake water levels. The two sets of figures were compared to reveal that $69 \%$ felt their port would be able to handle the rise expected at their port without building additional protections.

Figure 10 - SLR expectations and concern

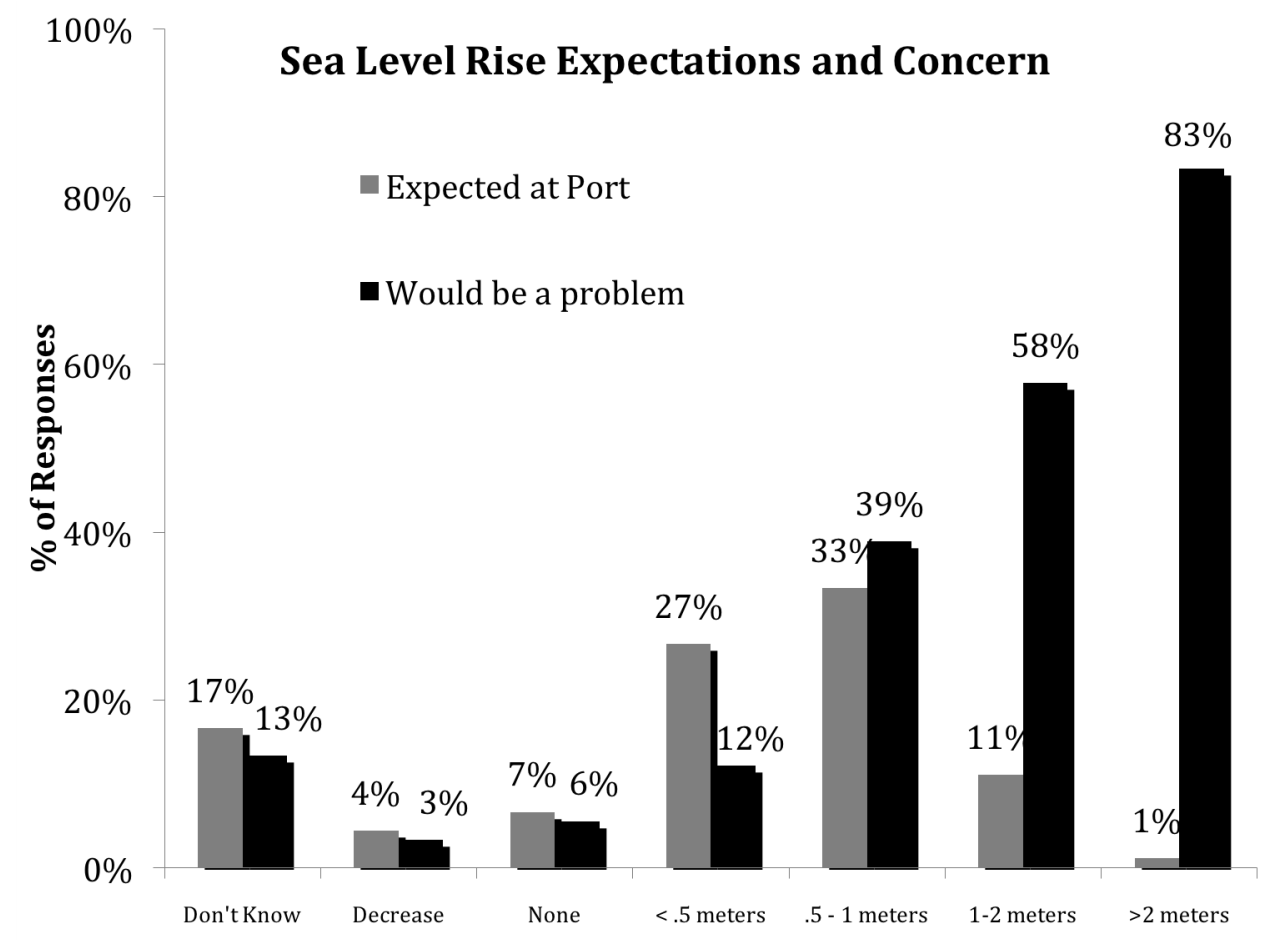

$46 \%$ or respondents who thought SLR would not be a problem at their port cited "SLR" as one of their three top concerns. Maybe respondents were not confident in their estimations of SLR, or perhaps their concern is only with a rise that occurs beyond 2100 . This contradiction indicates that more research is needed to help develop local projections for SLR. Most models are global in scale and utilize the "bathtub approach" 
of adding a uniform rise to all coastal areas (Bernstein et al. 2008). SLR and storm surges, however, will result in different threats to different areas (Mearns et al. 1999). Local SLR will vary with ocean circulation patterns, gravitational effects, land subsidence and other factors. Further knowledge would help seaport decision makers prepare their ports better for the rise expected in their region. Figure 11 illustrates the concern about SLR, as revealed in the survey, against a variety of projections for SLR based on different emissions scenarios. The various scenarios show a range of .8 to 1.8 meters of rise projected by 2100 (Vermeer and Rahmstorf 2009). At the 2060 mark, 39\% of ports would have a problem if the projections follow the mid to upper curve. The red dashed line at the bottom shows the typical lifespan of infrastructure that is built today.

Figure 11 - SLR concern as compared with SLR projections

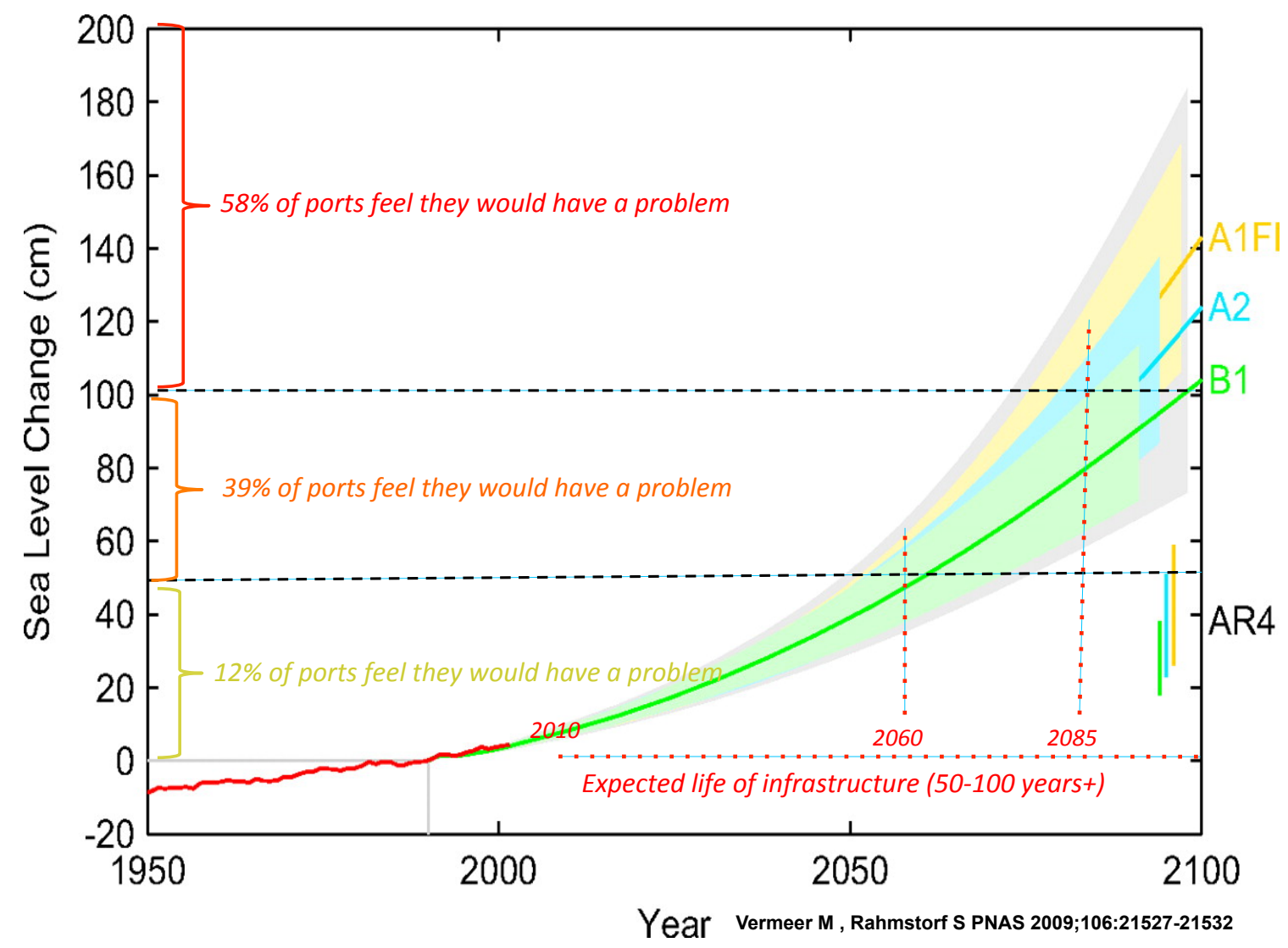

Respondents were asked who at their port knows the most about climate change adaption. The answers to this question give a sense of where the responsibility for climate change planning probably lies. Although climate change mitigation would most logically lie with the environmental departments, adaptation might fall to the engineers, the environmental team, the planning departments, or not have a clear leader. About a third felt that the environmental planner knew the most, closely followed by the chief engineer and port director. With a few exceptions noted above, we found no significant difference in responses to perceptions and attitude questions between ports in and out of storm belts, or those close and far from the coast. 


\section{Discussion}

\subsection{Limitations of research}

We believe that this was the first international survey of port authorities with respect to climate change adaptation. As such, there was no model upon which to base the current study. We limited our sample ports to members of the two leading port organizations. Within this sample frame, $26 \%$ of ports responded. This gives a good indication of how IAPH and AAPA members consider the issues, but leaves out many ports that are not members. Additionally, ports that responded may be more interested in climate change than ports that did not respond. As such, responses may be skewed toward port directors who are already concerned with these issues.

We designed the survey with the port director in mind, realizing that the task of responding to the survey might be passed on to another employee at the port. The survey could not be designed in a way that would be ideal for an engineer, an environmental manager, a planner, and any others who might end up filling it out. The survey ascertained perceptions, not actual knowledge of climate change. Although a broader sample would provide interesting results for comparison, we feel that this survey helps ground future research, identifying some key concerns, and verifying a clear need for more work in this area.

We also note that ports themselves are but one actor in a system of diverse actors that will need to collaborate to meet the challenges of climate change impacts. As such, similar surveys of port engineers, port regulators, port insurers, and other stakeholders would give a better-rounded overview of the range of concerns and perceptions that ought to be considered with respect to seaports.

\subsection{Implementing change at the seaport level}

The results of the survey show climate change adaptation as an issue of concern to the ports community. Of the 73 respondents with an opinion on the matter, $53 \%$ felt that climate change would have negative consequences on their operations. $86 \%$ (of 88 respondents) agreed that the port community needs to better understand how to address these issues. Although some ports have begun to create or implement new policies, the majority has not.

The port community has already taken steps to address the "mitigation" side of climate change, but has not yet begun to consider the implications of climate change on their own continuing operations. Many ports are actively working to reduce the impact of their operations on $\mathrm{CO}_{2}$ emissions. Both IAPH and the AAPA have sponsored workshops to help their members proactively respond to new regulatory changes that will require cleaner, greener operations. A 2008 AAPA 'Climate Change Workshop'' for example, focused on cutting greenhouse emissions and new regulations (AAPA 2008). The IAPH reports that its Port Planning and Development Committee will begin to explore the topic of adaptation in the coming two-years (Fer Van de Lar, personal communication, 2009). Given the uncertainties in the scientific models with regard to SLR and future storm event trends, it is not surprising that ports are not yet fully considering these impacts on their own operations. It is in each port's own self-interest to protect its operations if severe impacts are forecast for its given region. At this early stage of adaptation, ports 
around the world can work together to address impacts of climate change. IAPH launched the WPCI last year to urge ports to address mitigation and share their experiences among ports. A logical next step would be for WPCI to cover both mitigation and adaptation of climate change.

Ports are expanding and building new infrastructure. For example, about $69 \%$ of the ports surveyed say they will complete some major infrastructure project within five years. $75 \%$ of ports are designing these projects for the 1-in-100 year storm event. These projects are often on a large scale and incorporate a design life of several decades. Climate change is likely to make the 1 -in-100 year storm event occur with much higher frequency and potentially greater strength, making the 1-in-100 year storm design inadequate for the life of this new infrastructure. As an initial step, the $78 \%$ of respondents that indicated they did not have a storm response plan should assess their specific needs in this area and create appropriate response plans. And, if it is indeed the case that storm damages are not covered under $77 \%$ of respondents' port insurance policies, those policies should be reviewed and revised if necessary.

These results highlight one of the most challenging aspects of planning for climate change. Given that the capital-facilities planning horizon is short relative to the most widely accepted predictions of sea level change, the rational planning solution is to omit sea-level change as a major driver of those plans. However, we see a significant opportunity to develop incremental strategies that do not inadvertently complicate or prevent future planning for climate change. Planning for climate change demands a rethinking of a variety of paradigms. Impacts will occur beyond infrastructure design life and beyond the length of the average port administrator's career. In addition, uncertainty will always be an element that needs to be addressed through planning. Historical data are no longer adequate when planning for the coming century.

\subsection{Public policy}

$92 \%$ of ports represented in these results were public or public/private entities. Many are owned or operated by government port authorities. Since ports serve a critical role in the local, regional, and global economy, there is a high societal demand that ports remain efficient and functional in the coming century. Additionally, extreme events lead to devastating consequences for the surrounding environment. Petroleum, chemicals, or other cargo stored at a port can end up in the surrounding estuary when a port is inundated by flood. A rise in sea level also affects littoral drift and sedimentation patterns around a port, making its channel and basins unstable in depth and configuration. Hinterland transportation and intermodal systems could also be seriously affected. Policy makers take responsibility for protecting the public interest in a functioning economy and a healthy environment. Adaptation cannot be left to the ports themselves to implement alone. New policy on a local level could require ports to enhance resilience by engineering protective structures, elevating storage of pollutants, or simply creating better storm preparation strategies. In the case of extreme SLR, it might be necessary to relocate port facilities or even whole port cities. On a national level, funding will be required to assist ports in making necessary improvements. Because ports tend to operate on relatively short time horizons, policy makers need to ensure that the long-term measures for resilience are implemented. Assistance can be provided through, for example, the regulation of setbacks, design standards, and insurance requirements. 


\subsection{International aid}

Both developed and developing nations face high risks from climate impacts. However, developing nations generally lack the same levels of adaptive capacity that richer countries enjoy. As the World Bank recently reported, adaptation costs of developing countries alone are estimated to be between $\$ 75$ billion and $\$ 100$ billion a year from 2010 to 2050 , even if global warming is limited to around $2{ }^{\circ} \mathrm{C}$ (World Bank 2009). Low adaptive capacity of developing countries is likely to impose a serious burden for these countries' economies and trade. Ports in developing countries require international technical and financial assistance to implement proactive adaptation strategies that ultimately protect the global economy and environment. As evidenced by the scoring system outlined above, ports in low or lower-middle income countries had fewer climate policies in place at the time of the survey. This is an opportunity for ports in higher-income countries to share some of their climate planning tools and knowledge with those who have not yet taken steps toward adaptation. Organizations like the AAPA and IAPH could serve as appropriate facilitators for this kind of knowledge sharing. Additionally, guidelines for the development of National Adaptation Plans of Action, required for least developed nations to be eligible for certain UN funding, could specifically address strategies for building resilience.

\subsection{Direction for future research}

Results of this survey point to common ground, common terminology, and a starting point to help ports begin to create strategies to become more resilient in the coming decades. There are a number of opportunities for the scientific community and the ports community to engage in information sharing. It is striking to note that the vast majority of ports considered climate change adaptation to be something that the ports community should address and yet only $34 \%$ felt sufficiently informed. Scientific information on localized impacts of climate change is still quite limited. For instance, any reliable prediction of SLR for a specific port or coast cannot be found today. The same applies to local temperatures and storm patterns. Without scientific information, it is difficult for decision makers to take any specific action beyond raising awareness.

Given the difficulties of accurately predicting localized impacts of climate change, we consider it practical to embark on a risk-analysis approach to climate change. With the current level of port/coastal engineering knowledge and technical methodology, it is possible to simulate different scenarios of likely impacts to identify how vulnerable a port is to such risks. However, a port should be able to predict fairly accurately what will happen to it with different scenarios of climate change risks. It should then be able to study alternative measures to cope with predicted impacts and develop its own strategic long-term program to prepare for climate change. Drawing the explicit link between a port's planning and operating assumptions, the state of climate science, and the portcommunity's awareness of this science highlights the need for finer granularity in climate models. On a global scale, most ports are in the beginning stages of considering adaptation to climate change. There is an opportunity for the scientific community to engage with this sector to create the knowledge base needed to understand and improve the resilience and efficiency in the coming century.

Finally, the insurance sector must play a role in building resilience. We have 
found that this area is much more complicated than anticipated. Our survey question about insurance policies in place may have been a difficult one to answer. There is a wide range of insurance policies that govern and shoulder the risk to the "port." The cargo, the port employees, the various shippers, the infrastructure, and many other facets of port operations often carry different types of insurance from different firms. Insurers and reinsurers can incentivize risk-reducing strategies in advance of climate change impacts. The insurance industry itself has argued that it is "moving from being a passive climate change sufferer that has to sustain some very expensive consequences to becoming a proactive shaper of the future." (Geneva Association 2009).

\section{Conclusion}

This paper presented the results of a survey to answer the following four broad questions.

1) What are the characteristics of the ports and respondents? Based on these characteristics, how might we begin to divide ports into different categories of risk and vulnerability?

Results of the survey show only small differences in adaptation planning for ports across the world. In general, most ports had made few preparations for climate change. For most units of analysis, adaptation scores were very similar, with an average number of 1.18 policies per port. There were a few minor exceptions. For example, ports carrying standard insurance policies tended to have slightly more climate change policies in place. World Bank status was a good indicator of preparation, as ports in developed (high and middle income) countries had more climate change policies in place than those in developing (lower and lower-middle income) countries. We also found that within the US, ports in the Gulf Coast were better prepared than those in other regions of the US. As storm patterns change, ports that are in or near a storm belt will face more damages than those outside of a belt. We expected to find ports closer to storm belts having a higher level of preparedness. However, results show very little difference between these ports and others that are not near a storm belt. Likewise, we expected to find that ports influenced by tides, which face additional risks from SLR, would have more policies in place. Again, the survey results did not bear this out. We did, however, find that ports on the Great Lakes were quite concerned with dropping lake levels and how new conditions would impact dredging schedules and navigation.

2) What are ports' planning horizons in terms of infrastructure development, timelines, and responding to climate changes?

Ports are rapidly expanding. Almost all respondents were in the process of developing new infrastructure within the next five years. Most were not planning for climate change and have few policies in place that specifically address climate change adaptation. The American Continental regions reported the most policies already in place.

3) Upon what assumptions are ports basing long-range plans? How is climate change discussed at the port and amongst the port community?

Though building infrastructure that will last for many decades, most ports planning horizons were less than 10 years. Planning today should consider the possible impacts of 
SLR, increased flooding, and more intense hurricanes and cyclones. Designing infrastructure for an historical 100-year storm return period may no longer be appropriate. In general, ports were not discussing adaptation to climate change in staff meetings or in the ports community as a whole. The vast majority felt under-informed, but also felt that this is an important issue for their community.

4) What do port directors think the local and regional impacts will be? What climate changes would be problematic to their operations?

Respondents reported concerns with SLR, increases in storm events, waves, flooding, and other damages to their operations. Although SLR was noted as a top concern, most respondents also felt that their ports were adequately protected from the rise they expect to see in the next 100 years.

Climate change requires the ports community to come together to find solutions to complex problems. It is not only the port administrators who must take responsibility. Policy makers on every level, insurers, and NGOs need to find ways to share information and collaborate in creating a more resilient port system for the coming century. The results from this survey will be used in on-going research to better quantify the challenges seaports face due to climate change impacts, the adaptation strategy options they may employ, and the potential policy responses that may be designed to promote resilient ports. Though 2100 may feel like the distant future, adapting to climate change requires informed planning and a better understanding of when ports should begin implementing proactive adaptation strategies.

\section{Acknowledgements}

We thank the IAPH and AAPA, Prof. Pam Matson, Meredith Martino (AAPA), the CEE 129/229 class at Stanford, Dr. Mike Mastrandrea, and the survey respondents. We received funding support from a McGee Grant from the Stanford School of Earth Sciences and from a Planning Grant from the Sustainable Built Environment Initiative of the Woods Institute for Environment at Stanford University.

Alreck, PL and Settle, RB (1995), The survey research handbook (Irwin Chicago). American Association of Port Authorities (2008), 'Climate Change Workshop', Climate Change Workshop (Houston, TX: American Association of Port Authorities).

American Association of Port Authorities (2010), 'Harbors, Navigation and Environment Seminar and GreenPort Americas 2010 - Programs and Events', Harbors, Navigation and Environment Seminar and GreenPort Americas 2010 (Charlseton, $\mathrm{SC})$.

Bender, M. A., et al. (2010), 'Modeled Impact of Anthropogenic Warming on the Frequency of Intense Atlantic Hurricanes', Science, 327 (5964), 454-58.

Bernstein, L, Pachauri, RK, and Reisinger, A (2008), Climate change 2007: synthesis report (IPCC).

Bichou, K and Gray, R (2005), 'A critical review of conventional terminology for classifying seaports', Transportation Research Part A, 39 (1), 75-92.

Bierling, David and Lorented, P. (2008), 'Ports and Climate Change: Perceptions and Planning Practice', 2008 Texas Ports and Waterways Conference (Galveston, TX: Texas Transportation Institute). 
Brooks, MR (2004), 'The governance structure of ports', Review of Network Economics, 3 (2), 168-83.

California State Lands Commission (2009), 'A Report on Sea Level Rise Preparedness', (California State Lands Commission).

Dasgupta, Susmita, et al. (2008), 'The impact of sea level rise on developing countries: a comparative analysis', Journal of Climatic Change, 93 (3-4), 379-88.

Esteban, M., Webersick, C., and Shibayama, T. (2009), 'Estimation of the economic costs of non adapting Japanese port infrastructure to a potential increase in tropical cyclone intensity', IOP Conference Series: Earth and Environmental Science, 6 (32), 322003.

Federal Emergency Management Agency (FEMA) (2008), 'Hurricane Ike Impact Report', (Washington, DC).

Geneva Association (2009), 'The insurance industry and climate change - Contribution to the global debate', in Editor-in-Chief: Patrick M. Liedtke Editorial Managers: Susanne Le Roux and Françoise Jaffré (ed.), The Geneva Reports - Risk and Insurance Research No. 2. (The Geneva Association (The International Association for the Study of Insurance Economics)).

Hallegate, S., Patmore, N., Mestre, O., Dumas, P., Corfee-Morlot, J., Herwieger, C., Muir Wood R. (2008), 'Assessing climate change impacts, sea level rise, and storm surge risk in port cities: A case study on Copenhagen', (Organisation for Economic Co-Operation and Development).

Hallegatte, S (2007), 'The use of synthetic hurricane tracks in risk analysis and climate change damage assessment', Journal of Applied Meteorology and Climatology, 46 (11), 1956-66.

Hallegatte, S. (2008), 'An Adaptive Regional Input-Output Model and its Application to the Assessment of the Economic Cost of Katrina', Risk analysis, 28 (3), 779-99.

Hans Moser, Peter J. Hawkes, Øivind A. Arntsen, Pierre Gaufres, France Stephan Mai, Gernot Pauli, Kathleen D. White, (2008), 'Envicom - Task Group 3: Waterborne transport, ports and waterways: A review of climate change drivers, impacts, responses and mitigation', (International Navigation Association (PIANC), ).

Hoyle, BS and Knowles, RD (1992), Modern transport geography (Belhaven Press). Intergovernmental Panel on Climate Change (IPCC) (2007), 'Climate Change 2007: Impacts, Adaptation and Vulnerability', in M.L. Parry, Canziani, O.F., Palutikof, J.P., van der Linden, P.J., Hanson, C.E. (ed.), Contribution of Working Group II to the Fourth Assessment Report of the Intergovernmental Panel on Climate Change (Cambridge, UK).

International Association of Ports and Harbors 'NGO Consultative Status // IAPH', $<\mathrm{http}$ ://www.iaphworldports.org/about/ngo.html $>$, accessed 12/15/2010.

International Maritime Organization (IMO) 'International Shipping and World Trade Facts and Figures',

$<$ http://www.imo.org/KnowledgeCentre/ShippingFactsAndNews/TheRoleandImp ortanceofInternationalShipping/Pages/TheRoleAndImportanceOfInternationalShi pping.asp $x>$, accessed 02/10/2009.

Joint Legislative Committee on Performance Evaluation and Expenditure Review (PEER) (2006), 'The Impact of Hurricane Katrina on Mississippi’s Commercial 
Public Ports and Opportunities for Expansion of the Ports', (Jackson, MS: Mississippi Legislature).

Karl, T., Melillo, J., and Peterson, T. (eds.) (2009), 'Global Climate Change Impacts in the United States', (U.S. Global Change Research Program (USGCRP)).

Leiserowitz, Anthony, Maibach, Edward, and Roser-Renauf, Connie (2008), 'Six Americas: An Audience Segmentation', (George Mason University Center for Climate Change Communication).

Mearns, L. O., et al. (1999), 'Comparison of climate change scenarios generated from regional climate model experiments and statistical downscaling', J. Geophys. Res., 104 (D6), 6603-21.

Moser, SC and Tribbia, J (2006), 'Vulnerability to inundation and climate change impacts in california: Coastal managers' attitudes and perceptions', Marine technology society journal, 40 (4), 35-44.

National Research Council (NRC) (2009), 'Informing Decisions in a Changing Climate', Panel on Strategies and Methods for Climate-related Decision Support (Washington, DC: Committee on the Human Dimensions for Global Change, Division of Behavioral Sciences and Education), Executive Summary, p. 1.

Nicholls, R., S. Hanson, C. Herweijer, N. Patmore, S. Hallegatte, J. Corfee-Morlot, J. Chateau, and R. Muir-Wood (2007), 'Ranking Port Cities with High Exposure and Vulnerability to Climate Extremes: Exposure Estimates', OECD Environment Working Paper 1, ENV/WKP(2007)1 (Paris, France: OECD).

Pielke, Roger A (2007), 'Future economic damage from tropical cyclones: sensitivities to societal and climate changes. . ', Philosophical Transactions of the Royal Society A, 1-13.

Rahmstorf, Stefan (2007), 'A Semi-Empirical Approach to Projecting Future Sea-Level Rise ', Science, 315 (5810), 368 - 70.

Santella, N, Steinberg, LJ, and Sengul, H (2010), 'Petroleum and Hazardous Material Releases from Industrial Facilities Associated with Hurricane Katrina', Risk analysis, 30 (4), 635-49.

Simpson, M.C., Scott, D., Harrison, M., Silver, N., O’Keeffe, E., Sim, R., Harrison, S., Taylor,, M., Lizcano, G., Rutty, M., Stager, H., Oldham, J., Wilson, M., New, M., Clarke, J., Day, O.J.,, and Fields, N., Georges, J., Waithe, R., McSharry, P. (2010), 'Quantification and Magnitude of Losses and Damages Resulting from the Impacts of Climate Change: Modelling the Transformational Impacts and Costs of Sea Level Rise in the Caribbean (Summary Document)', (Barbados, West Indies).

Stern, NH and Britain, G (2006), Stern Review: The economics of climate change (30: HM treasury London).

Transporation Institute (2008), 'Industry Profile', Transportation Institute. $<$ http://www.trans-inst.org/industry-profiles.html>, accessed March 28, 2010.

United Nations Conference on Trade and Development (2008), 'Maritime transport and the climate change challenge', Note by the UNCTAD secretariat. (Geneva: United Nations).

United Nations Conference on Trade and Development (UNCTAD) (1985), 'Port development: A handbook for planners in developing countries', (New York: United Nations Conference on Trade and Development). 
United Nations Statistics Division 'Composition of macro geographical (continental) regions', (updated 15 Apr. 2009)

$<$ http://unstats.un.org/unsd/methods/m49/m49regin.htm>, accessed 03/15/2009.

United States Commission on Ocean Policy (USCOP) (2004), 'An Ocean Blueprint for the 21 st Century. Final Report', (Washington, DC: United States Commission on Ocean Policy).

United States Environmental Protection Agency (USEPA) (2008), 'Planning for Climate Change Impacts at U.S. Ports. White Paper prepared by ICF International for the USEPA'.

Vermeer, M and Rahmstorf, S (2009), 'Global sea level linked to global temperature', Proceedings of the National Academy of Sciences, 106 (51), 21527.

World Bank (2009), 'The Costs to Developing Countries of Adapting to Climate Change: New Methods and Estimates, Consultation Draft', The Global Report of the Economics of Adaptation to Climate Change Study. 